Rev. Biol. Trop., 48(2/3): 473-485, 2000

www.ucr.ac.cr www.ots.ac.cr www.ots.duke.edu

\title{
A management plan for the sport fishery of Parachromis dovii (Pisces: Cichlidae) in Hule lake, Costa Rica
}

\author{
Farid A. Tabash B. ${ }^{1}$ and Emilier Guadamuz S. ${ }^{2}$ \\ 1 Estación de Biología Marina, Universidad Nacional. P.O.B. 126-5400, Puntarenas, Costa Rica. Fax (506) 661-3635 \\ (atabash@una.ac.cr) \\ 2 Centro Naútico Pesquero, Instituto Nacional de Aprendizaje, Puntarenas, Costa Rica.
}

Received 28-IV-1999. Corrected 18-I-2000. Accepted 4-II-2000.

\begin{abstract}
A first attempt to regulate the fishing activity while preserving the species and its habitats is presented for Hule lake. We intensively sampled the "guapote" between March 1996 and April 1997 using monofilament gill nets and a floating line, collecting 421 individuals. P. dovii biomass was relatively low; this species had a long life cycle (8-10 years) and the growth oscillation was low $(C=0.3)$. Maximum life expectation was estimated at 12 years and the point of minimum growth coincided with the spawning that takes place between November and December. After spawning, $P$. dovii take around seven months to reach recruitment size $(54.6 \mathrm{~mm})$. The length for sexual maturity was $134 \mathrm{~mm} \mathrm{Lt}$, which indicates that this species is viable for reproduction soon after leaving the protection zones around the lagoon. "Guapote" sport fishing in the Hule lake is in equilibrium, the renewal rate is $80 \%$. An increment in the actual fishery effort is not recommended, since it could seriously affect the natural renewal capacity of the stock.
\end{abstract}

Key words: Cichlasoma, Parachromis, Costa Rica, stock assessment, management plan, conservation, sport fishing, Hule lake.

The Cichlidae family consists of numerous genera and species distributed in Africa, where their adaptive radiation in the great lakes has been investigated in detail (McKaye 1977). In the America's neotropical zone its distribution extends from Texas, United States, to Chile and Argentina (Darlington 1957, McKaye 1977, De Silva et al. 1984 and Bussing 1989).

The majority of the cichlids of Latin America belong to the Parachromis genus (Bussing 1998); are extremely heterogeneous in their feeding patterns (Yañez-Arancibia 1978, McGinthy 1984), habitat selection (McKaye 1977b, Rosales 1980), morphology (Meyer 1987) and population dynamics (Fields 1986, Gaspra-Dillanes et al. 1995 and MoralesBojórquez 1995).

P. dovii is distributed in Central America from middle Honduras to the great lakes and lagoons of Nicaragua and the slopes of Costa
Rica's mountain ranges (Miller 1966, Alpírez 1985). Its common name is "guapote" and it is the largest species of the family, reaching a total length of $650 \mathrm{~mm}$ (Anonymous 1996).

In lake Arenal, the species prefers moderate currents and rocky areas with bathymetric zonation accordance to the age (Bussing and López 1977 and Moya 1979).

In general, $P$. dovii can be found in environments ranging from shallow waters to rapid currents where it hides behind rocks or overgrowths. It occurs in streams waters and lakes between heights of 0 to $600 \mathrm{~m}$., and tolerates temperatures from 21 to $31^{\circ} \mathrm{C}$. It is highly piscivorous, eating tetras, poeciliids and cichlids, but it also ingest crustaceans and insects (Bussing 1987, 1998).

Most of the investigations on $P$. dovii refers to taxonomy, biology and ethology. Aldave (1985) presented some research on "guapote" 
biology in lake Arenal, including a brief study of their population dynamics. Campos (1986)) estimated that the "guapotes" occupy all of lake Arenal, preferring bays with vegetable cover and zones with an abundance of fallen trunks. McKaye (1977) reported the reproduction pattern of $P$. dovii in the lake Jilaloa, Nicaragua.

In this assessment plan we present a first attempt to regulate the fishing activity while, at the same time, preserving the species and its habitat.

\section{MATERIALS AND METHODS}

Between March 1996 and April 1997, specimens of $P$. dovii were collected in three sampling zones (Fig.1) in the Hule lake using 0.6 monofilament gill nets with a mesh size of 6.985 and $7.62 \mathrm{~cm}$. with a height of $3.8 \mathrm{~m}$. "Guapotes" were pooled according with the mesh size that they were captured.

Each month the sampling period were 3 days, the nets were placed in each one of the sampling zones during the night. Between 7 a.m and $8 \mathrm{a} . \mathrm{m}$, they were lifted to collect the catch of "guapotes". Then the net was left in

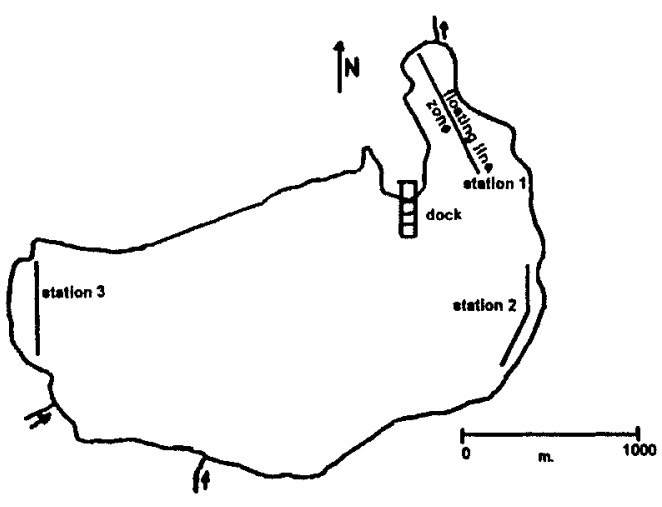

Fig. 1. Study areas. The collection stations are shown in relation to the dock location. the sampling zone until 4 p.m when it was moved to the following sampling zone, to repeat the procedure.

Parallel to this, a floating line containing 25 fishhooks \#7, 25 fishhooks \# 8, 25 fishhooks \# 9 and 25 fishhooks \# 10 placed in alternate form it was located in the west sector of the lagoon, a zone of shallow waters with a dense plant cover and many macroalgae and trunks. The floating line remained in this area during three days. Every 8 hours, the line was checked and the bait (sardine and "guapote") was changed.

Each captured "guapote" was placed in an ice box and, at the operation center, total length (mm), total weight $(\mathrm{g})$, sex, maturation state, and stomach content were estimated.

All "guapotes" captured were identified using the keys of Astorqui (1971) and Bussing (1977).

1. Feeding patterns: In all the "guapotes" analyzed, the gut was removed by dissection. Data on sex and maturity were collected. The gut content was removed directly from the stomach and placed in a vial containing ten-percent formalin as a fixative. Before samples were examined in detail, excess formaldehyde was removed by soaking the samples in several changes of water. Then, the samples were preserved in a $45-70 \%$ aqueous solution of alcohol. For quantitative description of the diet, the method of frequency of occurrence was used.

2. Sex ratio, maturation patterns and size at first maturity: The mean size at first maturity $\left(\mathrm{M}_{\mathrm{L}}\right)$ was determined at $95 \%$ confidence limits using the method of Udupa (1986), based on accumulative percentage frequency curve of maturation stages. The maturation stages of each guapote analyzed was determined using the method of Holden and Raitt (1975). 
3. Stock assessment: Length frequency analysis was applied to estimate growth parameters, using the von Bertalanffy growth curve incorporated in FiSAT software (Gayanillo et al. 1996). It was assumed that the length frequency data are representative of the population, that the growth patterns are repeated from year to year, that the von Bertalanffy formula describes the mean growth in the population and that all fish in the samples have the same growth parameters. The seasonal oscillation (C) and the point of minimum growth (WP) were also calculated.

Parameters of the length-weight relationship were estimated using least squares regression on log-transformed data with bias correction. A total of 421 fishes ranging from 100$630 \mathrm{~mm}$ were used for the analysis.

Total mortality $(Z)$ was estimated from data corrected for gear selectivity using the method of Moureau (1988), taking into account the complete length frequency distribution obtained with the gill-net plus the "guapotes" caught with the floating line. Natural mortality (M) was estimated from the empirical equation of Pauly $\left(1980^{\mathrm{a}}\right)$. Fishing mortality $(\mathrm{F})$ was estimated by subtraction of $\mathrm{Z}$ and $\mathrm{M}$. The optimum exploitation $\operatorname{rate}(E=F / Z)$, was computed for a preliminary assessment of whether the stock is lightly $(\mathrm{E}<$ $0.5)$ or heavily exploited ( $\mathrm{C}>0.5)$.

Identification of selection patterns were estimated by backward projection of the straight portion of the catch curve. Recruitment patterns were obtained projecting the length frequency data available backward into the time axis. Estimations of yield and biomass per recruit were plotted.

Using the results of the assessment and statistics on the number of visits by occasional and sport fishermen, recommendations were made for the management of the "guapote". in the Hule lagoon.

\section{RESULTS}

1. Feeding patterns: Of the six feeding categories that were determined, rest of fishes and insects presented the major frequency of occurrence. The rest of fishes represented $37 \%$ of the diet, while the insects presented $26.8 \%$ (Table 1). The category, rest of fishes, was composed mainly of tetras (Astyanax aeneus),

"olominas" (Poecilia gillii) and juveniles of P. dovii.

\section{TABLE 1}

Presence of several categories of food in stomaches of $\mathrm{P}$. dovii, frecuency of occrrence in the Hule lake, during the period March 1996 to April 1997.

$\begin{array}{lcc}\text { Feeding category } & \text { Proportion } & \begin{array}{r}\text { Frecuency } \\ \text { of occurrence }\end{array} \\ \text { Rest of fishes } & 0.09 & 175 \\ \text { Insects } & 0.28 & 124 \\ \text { Microcrustaceans } & 0.23 & 39 \\ \text { Vegetable tissue } & 0.05 & 27 \\ \text { Sediment } & 0.03 & 19 \\ \text { Digested material } & 0.32 & 79\end{array}$

P. dovii size affected the composition of stomach contents. The juveniles consumed more poecilids and microcrustaceans than the adults, the latter supplemented their diet with insects (Table 2).

\section{TABLE 2}

Presence of several feeding categories in P. dovii, according with the size classes sampled in the Hule lagoon.

$\begin{array}{lccc}\text { Feeding category } & <100 & 100-400 & 400-630 \\ & & & \\ \text { Rest of fishes } & 8.6 & 19 & 12.2 \\ \text { Insects } & 65.5 & 47.6 & 19.5 \\ \text { Microcrustaceans } & 41.4 & 33.3 & 18.3 \\ \text { Vegetable tissue } & 8.6 & 14.3 & 4.9 \\ \text { Sediment } & 1.7 & 4.7 & 4.6 \\ \text { Digested material } & 43.1 & 47.6 & 32.4\end{array}$

The temporal and spatial variations that $P$. dovii presented in the composition of their diet (Table 3), demostrate that even when the sampling zones are relatively close, the availability of food was different; this could influence the distribution of the population of "guapote" along the sampling stations in the lake. Similar results were reported by Aldave (1985) in lake Arenal. 
Proportions of food categories in the diet tended to change with length class, but there didn't seems to be a definitive pattern. The number of "guapotes" with empty stomach increased with the maturation stage; maybe the occurrence of prey capture will decreases when the "guapote" approach their maturation peak.

TABLE 3

Proportions of frequency of occurrence of several food categories in $\mathrm{P}$. dovii for the sampling stations ubicated in the Hule lagoon.

$\begin{array}{lccc}\text { Food category } & \text { Station 1 } & \text { Station 2 } & \text { Station 3 } \\ & & & \\ \text { Rest of fishes } & 10.6 & 9.4 & 8.5 \\ \text { Insects } & 18.8 & 23.7 & 18.8 \\ \text { Microcrustaceans } & 22.1 & 21.2 & 16.0 \\ \text { Vegetable tissue } & 8.2 & 4.4 & 0 \\ \text { Sediment } & 6.5 & 2.5 & 0.9 \\ \text { Digested material } & 31.1 & 41.8 & 25.5\end{array}$

2. Sex ratio, maturation patterns and size at first maturity: From 421 individuals collected during the sampling period $47 \%$ were males and $53 \%$ females. The sex ratio in the population sampled was 1: 1 (Fig.2). There were significantly (Mann-Whitney Utest, $\mathrm{p}<0.1)$ more inmature males and females in the sample period in the rainy season than in the transition and dry season (Table 4). With respect to maturity, $P$. dovii presents successive maturation patterns with seasonal spawning peaks. Sexually mature guapotes made up the largest proportion during November and February. McKaye (1977) reported a maturation peak of "guapotes" in Jilaloa lake, Nicaragua during February and April; Campos (1986) in lake Arenal, indicated that $P$. dovii probably spawn during August or September.

TABLE 4

Percentage of each gonadic maturation phase in $\mathrm{P}$. dovii population, during the sampling period in the Hule lagoon.

$\begin{array}{lcccc}\text { Month/Year } & \text { Phase I } & \text { Phase II } & \text { Phase III } & \text { Phase IV } \\ \text { March /96 } & & & & 6.4 \\ \text { April } & 5.8 & 0 & 8.8 & 7.6 \\ \text { May } & 17.4 & 0 & 11.3 & 1.2 \\ \text { June } & - & 0 & - & 0 \\ \text { July } & 14.2 & 0 & 0 & 0 \\ \text { August } & 17.9 & 0 & 6.2 & 0 \\ \text { September } & 5.8 & 0 & 5.0 & 0 \\ \text { October } & 9.5 & 0 & 11.9 & 4.6 \\ \text { November } & 6.3 & 0 & 5.0 & 5.5 \\ \text { December } & 2.6 & 0 & 25.1 & 4.6 \\ \text { January/97 } & - & 0 & 17.6 & 25.2 \\ \text { February } & 0 & 0 & 6.9 & 19.8 \\ \text { March } & 4.2 & 0 & 1.9 & 12.4 \\ \text { April } & 1.6 & 0 & 5.0 & 15.6\end{array}$

However, $42 \%$ of the population was immature (phase I), $36 \%$ was mature (phase III) and $22 \%$ had spawned (phase IV). Phase II is a stage slightly previous to the stage of full maturity, probably this stage overlaps with phase III.

The increments in the frequency of spawned guapotes during December and February, indicate that the more important spawning peak coincides with the transition period between rainy and dry season.
Length at first maturity oscillated for the males between 144 and $154 \mathrm{~mm} \mathrm{Lt}$. and for the females between 134 and $142 \mathrm{~mm} \mathrm{Lt}$, which corresponds with an age of 8.3 months and 7.6 months respectively. The maximum life expectation was estimated between 10 and 12 years, based on the growth rate calculated from the modal progression analysis. 


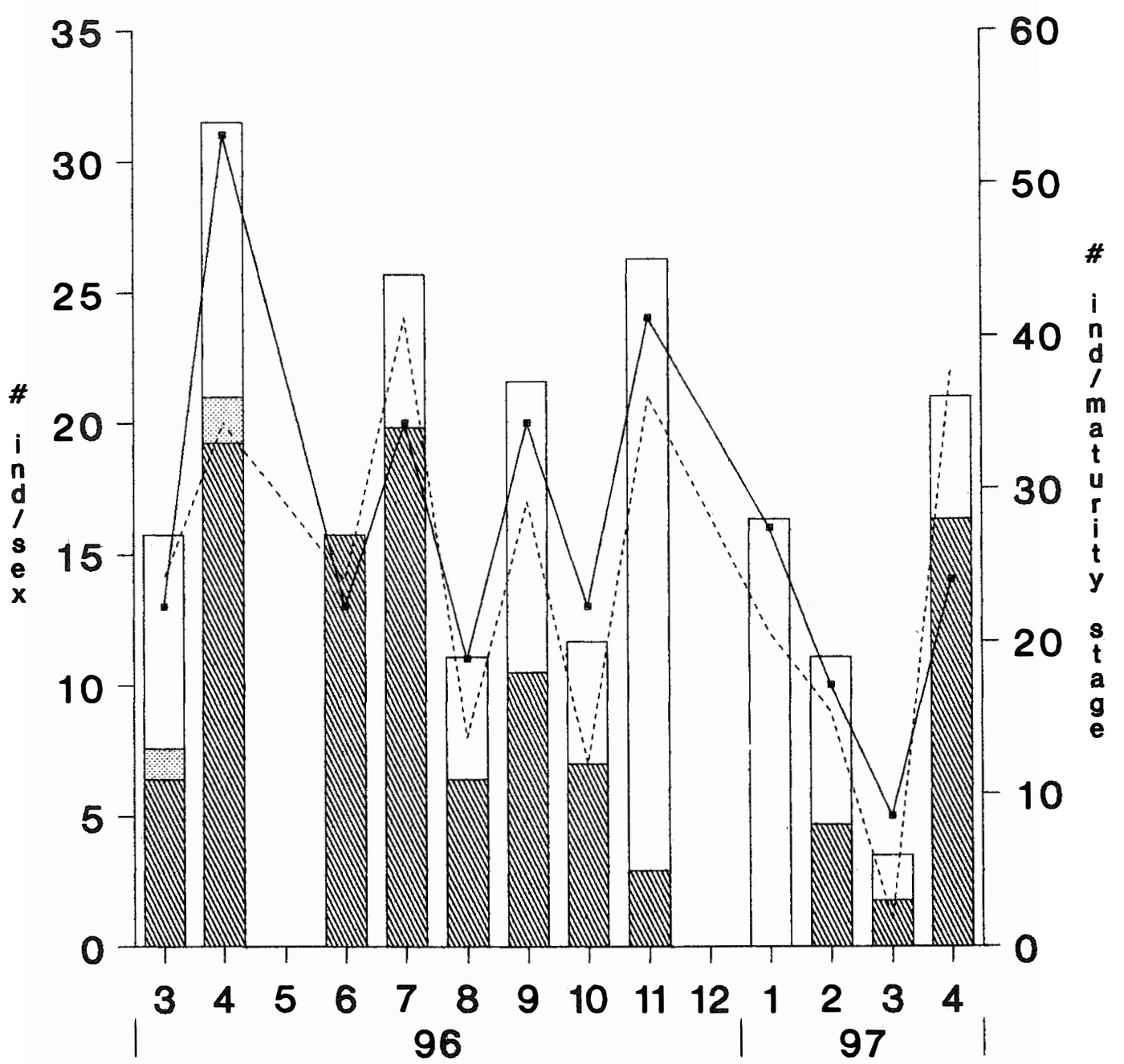

Month/Year

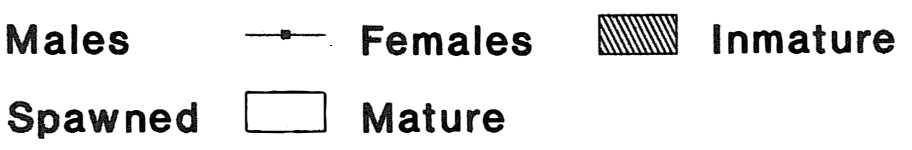

Fig. 2. Variations in the relation male: female and in the maturation stages obtained during the sample period in $P$. dovii in the Hule lake, Costa Rica.

3. Stock assessment: According to the growth parameter estimates with the von Bertalanffy growth equation, obtained through the FiSAT program, $P$. dovii in the Hule lake present a long life span, slow growth rate and weak growth seasonality $(C)$. The period of minimum growth (WP) was between November and December, the same period of maximum maturation stage. The grow th equation obtained in P. dovii was: 


\section{$\mathrm{Lt}=621$}

$\left[1-\mathrm{e}^{-0.64(t+0.88)-0.3 * 0.64 / 2 \Pi(t-0.42)-\operatorname{SIN} 2 \Pi(0.88-0.42))}\right]$

where $L_{\infty}=621 \mathrm{~mm}$ $\mathrm{C}=0.3$

In Fig.3, the length frequency distribution

shows that the "guapote" population is composed of approximately two cohorts and that the maturation patterns are continuous, suggesting that the population was composed of definite age groups.

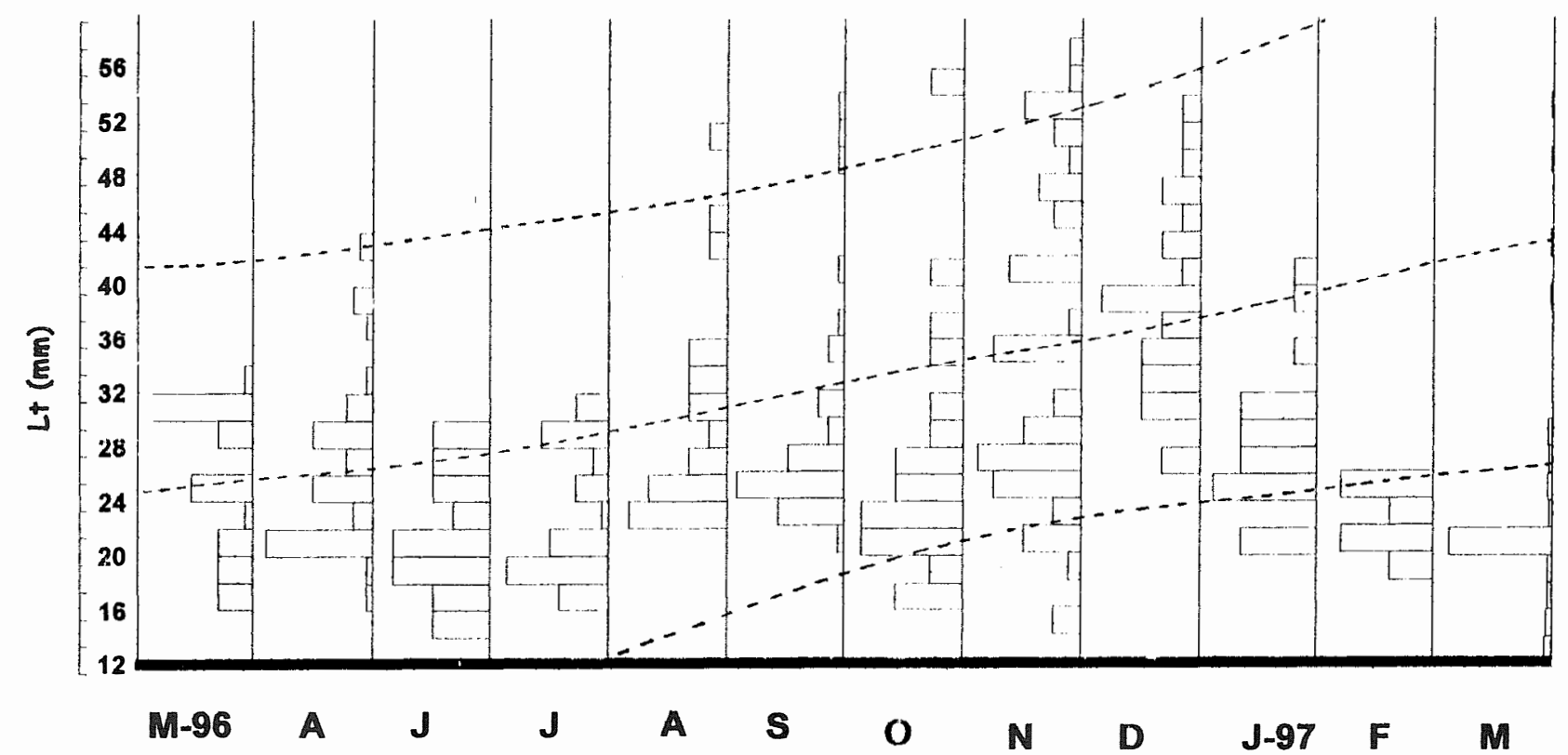

Fig. 3. Length frequency distribution and growth curves obtained for $P$. dovii population in the Hule lake, Costa Rica. 
Biometry: Hartnoll (1974) showed that the growth rate of any organ usually changes during ontogeny and that the growth constant is characteristic within each growth phase. For the "guapote" population, the relation was established with 421 data pairs. The minimum length was $120 \mathrm{~mm} \mathrm{Lt}$. and the maximum was $560 \mathrm{~mm} \mathrm{Lt}$, while the weight oscillated between $41 \mathrm{~g}$. and 2053,6 g. The length-weight relationship was:

$$
\mathrm{W}=0.0000241 \mathrm{Lt}^{2.95}(\mathrm{r}=0.98, \mathrm{~s} . \mathrm{d}=0.19)
$$

Aldave (1985) and Campos (1986) report similar results in their analyses of the guapotes of lake Arenal. In the females the equation was: 0.29)

$\mathrm{W}=0.0000354 \mathrm{Lt}^{2.96}(\mathrm{r}=0.93, \mathrm{~s} . \mathrm{d}=$

The minimum length was $110 \mathrm{~mm} \mathrm{Lt}$. and the maximum $532 \mathrm{Lt}$., while weight varied from $39 \mathrm{~g}$. to $1741.8 \mathrm{~g}$. In males the lengths varied between $110 \mathrm{~mm}$ and $564 \mathrm{~mm} \mathrm{Lt.,} \mathrm{cor-}$ responding to weight between $37 \mathrm{~g}$. and $2063,6 \mathrm{~g}$. respectively. The length-weight relationship for males was:

$$
\mathrm{W}=0.0000541 \mathrm{Lt}^{2.79}(\mathrm{r}=0.95, \mathrm{~s} . \mathrm{d}=0.19)
$$

Taking into account that the values "a" and " $b$ " obtained with the exponential equation have a biological interpretation, where " $a$ " is the condition factor and " $b$ " is a relative growth coefficient representing the isometry that each guapote has in its growth, then "a" and " $b$ " show an inverse relationship (Fig.4).

The condition factor increases from November to February, while the isometry factor decreases, during the months of maximum maturation stage. During those months the guapotes using more energy for the generation of sexual products, and therefore decrease their relative growth.

In terms of resource management, it is possible to detect the maturation and spawning periods and relate them with the monthly vari- ation of the "a" and "b" parameters. This means that in order to control the annual establishment of closed seasons, it is possible to use the biometric relationship. Staff can be easily trained to collect this type of information.

Mortality and exploitation levels: It is clear that "guapote" biomass initially depends on the level of fishing effort, which increases considerably during the dry season (January to April). During the rainy season (May to October), the survival of the juveniles is relatively stable in the reproduction zones, considering that maximum spawning occurred during the transition of rainy to dry season (November to January) the spawning was presented. Therefore, for a resource management professional to predict with confidence the maximum exploitation levels, it is necessary to predict effectively the annual levels of abundance, on which recruitment patterns are dependent.

Total mortality $\left(\mathrm{Z}=3.14\right.$ year $\left.^{-1}\right)$ is quite influenced by fishing than natural mortality $\left(\mathrm{F} / \mathrm{M}=0.91 \text { year }^{-1}\right)_{\text {which }}$ coincides with the exploitation rate obtained $(\mathrm{E}=0.48)$. It is evident that the population is close to the Maximum Sustainable Yield, in the equilibrium point, this means that recruitment barely replaces the "guapotes" fished.

The length of first capture $\left(\mathrm{Lc}_{50 \%}=149.6\right.$ $\mathrm{mm}$ ) was quite close to the female length at first maturation $(138 \mathrm{~mm})$ and in the males, is the same length. This is a reflection of the exploitation level that the guapotes are being subjected. The probability that they are fished before reproducing one time in their life is almost 50\%.

Population/Recruitment relationship: Taking into account that the population of guapote in the Hule lake was exactly in the equilibrium point and that the death probability by different causes than natural mortality is high, the recruitment levels are relatively low. During the year, between August and September, $45 \%$ of the recruits enter the population that is subject to fishing. This leads to the estimate that after spawning, larval development in the protected areas of the lake takes approximately seven months until the juvenile stage is reached (Fig.5). 




Fig. 4. Condition factor (-) and isometry value (_ _. )relationship obtained in P. dovii in the Hule lake, Costa Rica. 


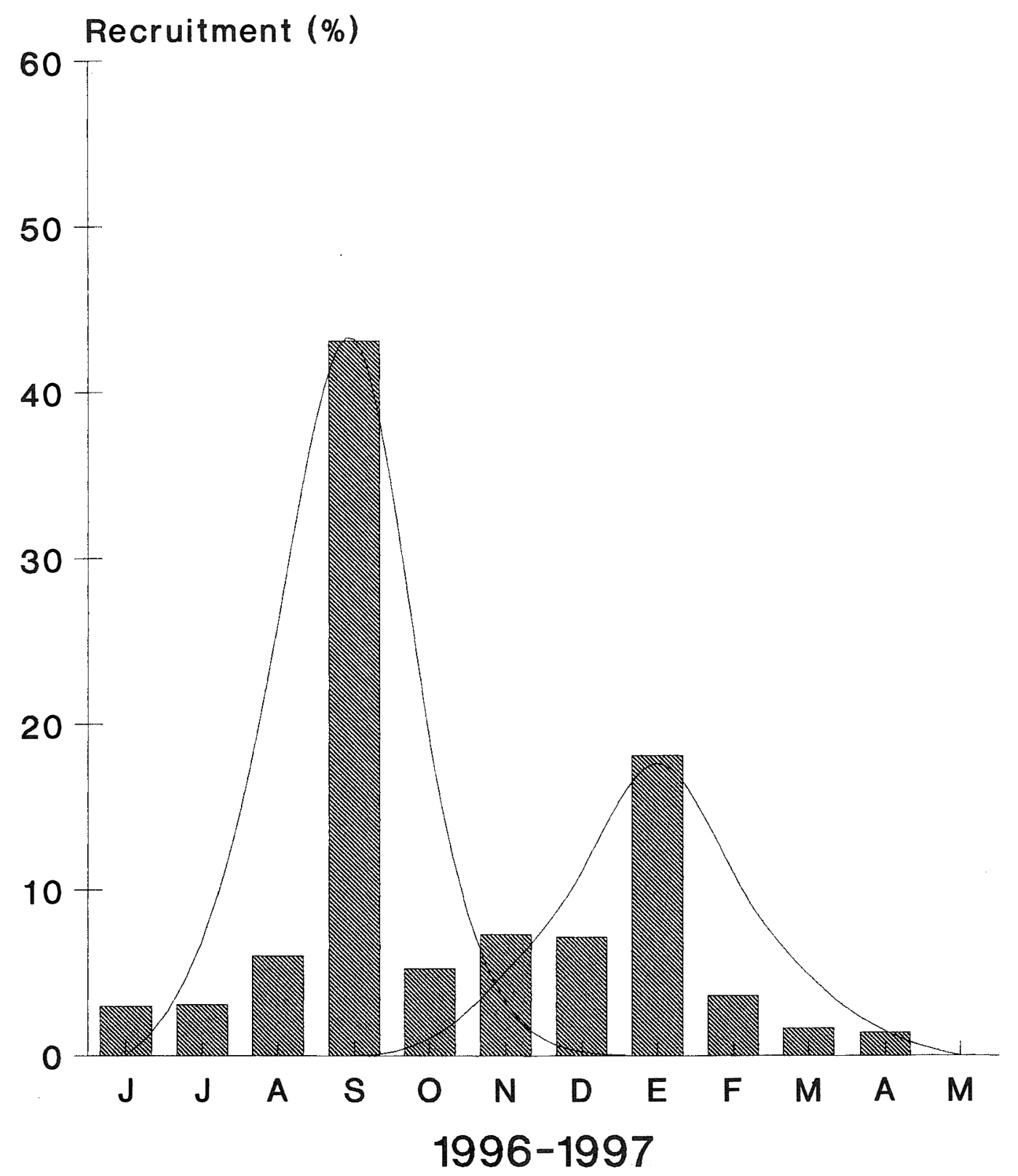

Fig. 5. Recruitment patterns for $P$. dovii population, obtained during the sampling period in the Hule lake, Costa Rica.

Relative Yield and Biomass per Recruit: This assessment and yield model describes changes in the "guapote" stock between 1996 and 1997, as a result of the change in the fishing effort applied during that period. The models of yield per recruit and biomass per recruit explains how recruitment and biomass are affected by an increase in the fishing mortality level (F) or fishing effort (f).

The natural renewal rate under the actual conditions already is about $80 \%$, meaning that under the actual level effort, $80 \%$ of the 
recruits have to replace the "guapotes" fished. Therefore, yield per recruitment under the actual exploitation rate (E) is too low (Fig.6), according to the fishery effort that at this moment is applied without controls over sport fishing licenses.

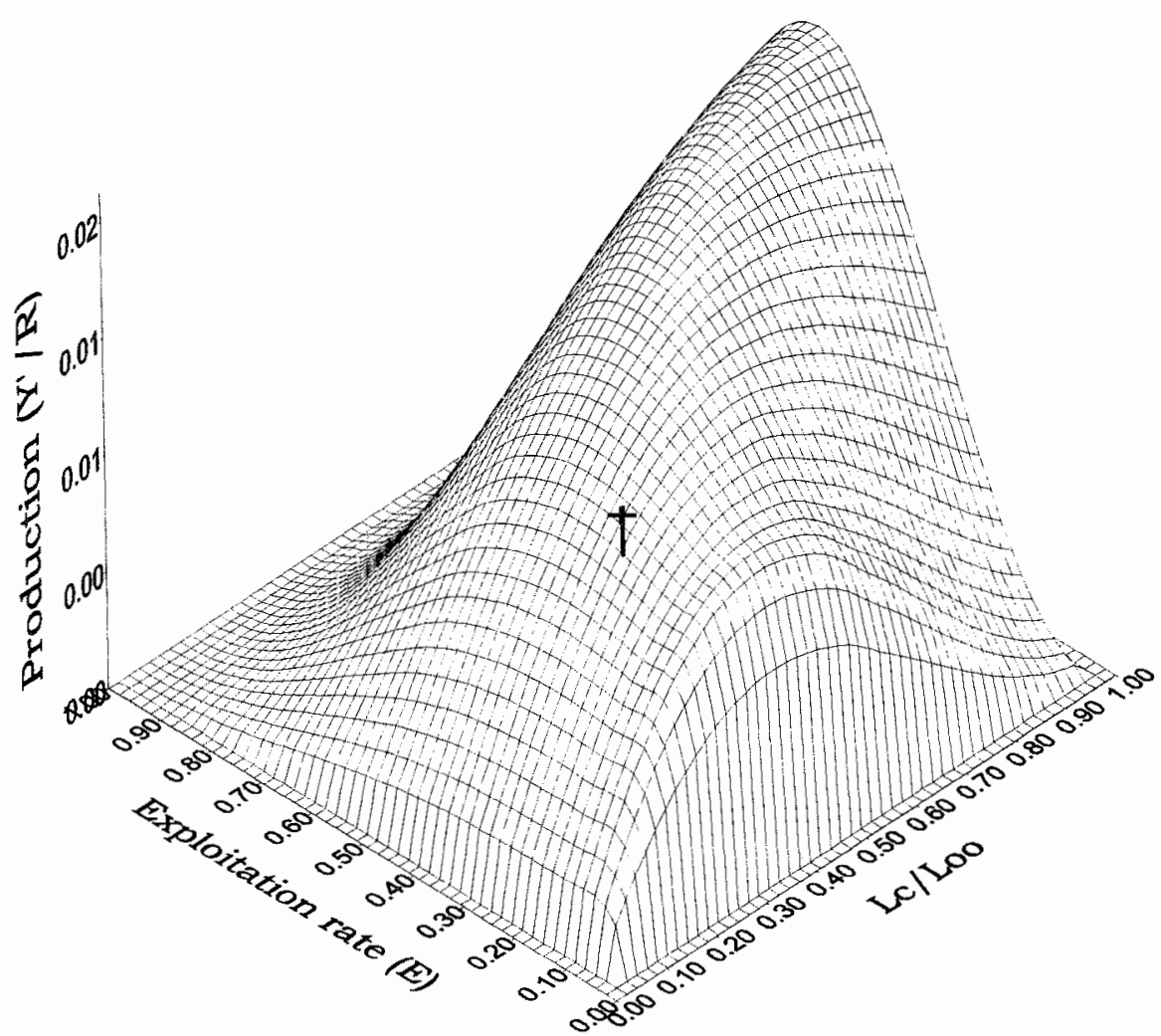

Fig. 6. Relative yield per recruitment ( $\left.\mathrm{Y}^{\prime} / \mathrm{R}\right)$ estimated for $P$. dovii population in the Hule lake, Costa Rica.

Recommendations for management: Actions suggested.

1. Assessment of the $P$. dovii stock should be carried out periodically to detect changes in the dynamics of the stock, including variables like the number of cohorts, the spawning process, growth rate and environmental variables that can serve as "quantitative marks of the state of the "guapote" population.

2. Is necessary to start biomass studies, using a capture-recapture model. This allows to know the abundance level, relative growth and survival of the "guapotes".

3. According with the results of the assessment process, a restocking project will be implemented.
4. The environmental variables that affect the abundance and distribution patterns of $P$. dovii in the lagoon and their relationship with the dry and rainy season, should be examined.

5. With the cooperation of the Association of Communal Development and the staff of the. Area de Conservación Cordillera Volcánica Central (ACCVC) of the Ministerio del Ambiente y Energía (MINAE), a pilot catch and effort data recording system (CEDRS) should be established.

6. The minimum length of capture for the "guapotes" of the Hule lake, should be 150 mm Lt. 
7. According to the census of weekly numbers of sport fishers in the lake, carried out during two years (1996-1997), the prime fishing were Saturday and Sunday, with an average of 35 fishermen per day, during the dry season. In the rainy season, the average of number of fishermen for those same days, decreased to 10 per day. This information, related to the analysis of relative yield and biomass per recruit and to the mean number of fish per day/fisherman (3 fishes), allows a maximum number of fishermen per day of 15 .

8. The only type of fishhook to be used is the “ $O$ 'Shaughlessy ( $1 / 0$ or $2 / 0)$; line resistance can be left for the fishermen to choose.

9. A closed season of three months (November 15 to January 15) should be established in 2001. During this closed season, assessment should be started, mainly on maturation and spawning patterns. Depending on the results of this study, in 2002 one or two mobile closed seasons of 1 month each should be established to protect the spawning peaks of the "guapote" stock.

10.The areas of the Hule lake indicated in Fig. 7 , should be permanently closed to the sport fishery, because between $25 \%$ and $35 \%$ of the fingerlings develop in these areas and possibly are reproduction zones.

11. It is recommended to allow the fishing of guapote only in the sectors indicated (Fig.7).

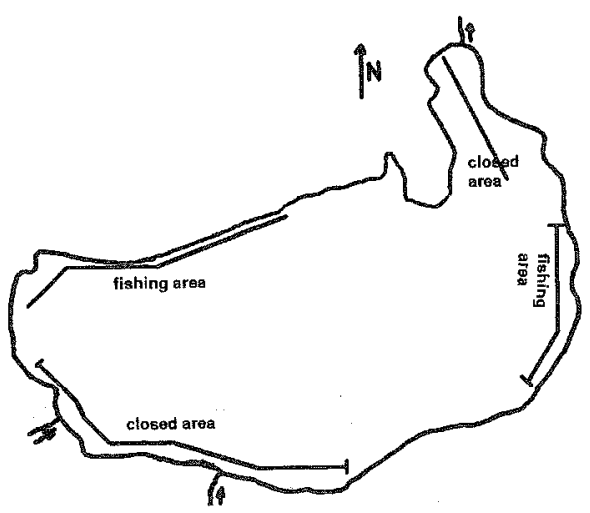

Fig. 7. Fishing and permanently closed areas suggested in the Hule lake, for the sport fishery of the "guapote lagunero".
12. In each one of these fishing sectors it is recommended to construct two bases of cement with a clearly visible ruler incorporated. The ruler will be of $20 \mathrm{~cm}$. length, highlighting a length of $15 \mathrm{~cm}$, with the legend "length of minimum capture allowed, if your fish doesn't reach this length, remove the hook and return the fish to the water".

13. It is imperative to construct a control stall, where the park-guard has the allowing responsibilities:

- restrict the access of sport fishermen to 15 per day.

- hand out the control and registration sheet to each sport fisherman.

- inform the fishermen about the fishing regulations.

- collect the basic biometric information on the catches.

\section{ACKNOWLEDGMENTS}

We thank Elizabeth Ramírez, head of project: "Use plan of the Hule and Río Cuarto lagoons by Sustainable Development" for the grants provided. At Universidad Nacional (UNA) and Instituto Nacional de Aprendizaje (INA) for the financial support and other facilities. To Anne Van Dam and Roxana Víquez for their suggestions and style corrections.

\section{RESUMEN}

Un primer intento para regular la actividad de la pesca deportiva para el guapote lagunero, Parachromis dovii mediante los resultados de un programa de evaluación del recurso y del estudio de la dinámica poblacional de esta especie se presenta. La biomasa del guapote es relativamente baja. La especie presenta un ciclo de vida largo ( 8 a 10 años) con una baja oscilación en el crecimiento $(C=$ $0.3)$, la expectativa de vida máxima estimada fue de 12 años y el punto de mínimo crecimiento coincidió con el período de desove (entre Noviembre y Diciembre). Luego del desove, $P$. dovii permanece en las áreas protegidas cerca de 7 meses hasta alcanzar la talla de reclutamiento $(54.6 \mathrm{~mm} \mathrm{Lt})$. La longitud de primera maduración fue de $134 \mathrm{~mm} \mathrm{Lt}$, lo que indica que esta especie es apta para reproducirse poco tiempo después de haber abandonado las áreas de protección, ubicadas alrededor de la laguna. 
También se describen algunos aspectos de su biología. La pesca deportiva del guapote en la laguna Hule mantiene aún a la población en equilibrio, la tasa de renovación natural se estima en $80 \%$, por lo que no se recomienda permitir un incremento en los niveles actuales de esfuerzo pesquero, dado que esto afectaría seriamente la capacidad de renovación natural de $P$. dovii.

\section{REFERENCES}

Aldave, G.T. 1985. Algunos aspectos biológicos del guapote Cichlasoma dovii (Gunther 1864) (Pisces: Cichlidae) en el embalse Arenal, Guanacaste, Costa Rica. Reporte de investigación, Escuela de Ciencias Biológicas, Universidad Nacional 29 p.

Alpírez, O. 1985. Ictiofauna de la vertiente del Pacífico de Costa Rica. Brenesia 23: 2-10.

Anonymous. 1996. Concepts, design and data source. ICLARM., Manila, Phillipines. 179 p.

Astorquí, I.S. 1971. Peces de la cuenca de los grandes lagos de Nicaragua. Rev. Biol. Trop. 16: 86-99.

Bertalanffy, L. von. 1934. Untersuchengen uber die Gesetzlichkeiten des Wachstums. 1. Allgemeine Grundlagen der Theorie. Roux' Arch. Entwicklungs mech. Org., 131: 613-653. In: Sparre, P. y S.C. Venema. 1994. Introducción a la evaluación de recursos pesqueros tropicales. Parte 1. Manual FAO Doc. Téc. Pesca. No. 306.1. Rev.1. 498 p.

Beverton, R.J.H. \& S.J. Holt. 1957. On the dynamic of exploited fish populations. Fish. Invest. 2: 533 p.

Bussing, W.A. 1987. Peces de las aguas continentales de Costa Rica. Editorial Uni. Costa Rica., San José, Costa Rica. 271 p.

Bussing, W.A. 1989. Cichlasoma loisellei, a new nandopsis group cichlid fish from Central America. Rev. Biol. Trop. 37: 153-161.

Bussing, W.A. 1998. Peces de las aguas continentales de Costa Rica / Freshwater fishes of Costa Rica. Editorial de la Universidad de Costa Rica. San José, Costa Rica. 2da. edición, 468 p.

Bussing, W.A. \& M. Martin. 1975. Systematic status, variation and distribution of four Middle American cichlids fishes belonging to the Amphilaphus species group, genus Cichlasoma. Nat. Hist. Mus. L.A. Co., Contrib. Sci. 269: 1-41.

Bussing, W.A. \& M.I. López. 1977. Distribución y aspectos ecológicos de los peces de las Cuencas hidrográ- ficas de Arenal, Bebedero y Tempisque, Costa Rica. Rev. Biol. Trop. 25: 13-37.

Campos, J.A. 1986. El recurso pesquero del guapote (Cichlasoma dovii) en el embalse de Arenal, Costa Rica. Rev. Biol. Trop. 34: 215-219.

Darlington, S.L. 1957. Comportamiento parental en Cichlasoma facetum (Jenyns) (Pisces: Cichlidae) Rev. Biol. Urug. 6: 31-38.

De Silva, J.T. 1984. Size and shape in ontogeny adn phylogeny of the cichlids in the world. Paleobiology 5: 296-317.

Gaspar-Dillares, M.T., A.S. Iturbide., P.G. Yoval \& D.L. García. 1995. Dinámica poblacional y biomasa desovante de la anchoa (Anchoa mitchilli) en la laguna de Tamiahua., Ver., México en 1985 y 1986. INP-SEMARNAP., México.Ciencia Pesquera 11: 21-27.

Gayanillo, F.C., D. Pauly \& P. Sparre. 1994. The FAOICLARM Stock Assessment Tools (FiSAT) User's guide. FAO computerized Information Series (Fisheries)., No. 6. Rome, FAO. 186 p.

Hartnoll, J.L. 1974. Species interaction in assessment of fish-stocks with special application to the North sea. Dana. 5: 1-44.

Holden, M.J. y D.F.S. raitt (eds.). 1975. Manual de Ciencia Pesquera. Parte 2. Métodos para investigar los recursos y su aplicación. Doc. Téc. Pesca. FAO. 115: $21 \mathrm{p}$.

McGinty, G.V. 1984. Biological versatility, evolution and food resource exploitation in African cichlids fishes. Amer.Zool. 15: 427-454.

McKaye, K. 1977. Competition of breeding sites between the cichlids fishes of the Lake Jilaloa, Nicaragua., Ecology 58: 291-302.

McKaye, K. 1980. Seasonality in habitat selection by the color morph of Cichlasoma citrinellum and its relevance to sympatric speciation in the family Cichlidae. Env. Biol. Fish. 5: 75-78.

Meyer, A. 1987. Firts feeding success with two tytpes of prey by the Central American cichlids fish, Cichlasoma managuense (Pisces: Cichlidae): Morphology versus behaviour. Env. Biol. Fish. 18: 127-134.

Miller, R.R. 1966. Geographical distribution of Central America freshwater fishes. Copeia 141: 773-802. 
Morales-Bojórquez, E. 1995. Estimación del tamaño poblacional y el coeficiente de capturabilidad de la tilapia (Oreochromis aureus) por varios métodos de extracción sucesiva. INP-SEMARNAP. Ciencia Pesquera 11: 40-44.

Moreau, J. 1988. Estimation of natural mortality from selection and catch length-frequency data: a modification of Munro's method and application example. Fishbyte 6: 10-12.

Moya, M.R. 1979. Estudio sistemático de los guapotes de América Central (Osteichthyes: Cichlidae: Cichlasoma). Tesis de grado Universidad de Costa Rica. 79 p.

Ricker, W.E. 1975. Computation and interpretation of biological statistics of fish populations. Bull. Fish. Res. Board. Can. 382 p.
Rosales, J. 1980. Un estimado preliminar sobre la densidad por unidad de área y selección del tipo de hábitat del guapote tigre Cichlasoma dovii en el sector de Caño Negro. Trab. Inv. Tut. Esc. Cienc. Biol. Universidad Nacional. 56 p.

Sparre, P.E., S.C. Ursin and S.C. Venema. 1989. Introduction to tropical fish stock assessment. Part 1. Manual FAO.Fish. Tech. Pap., No. 306.1., Rome, FAO. 337 p.

Yáñez-Arancibia, A. 1980. Taxonomía, ecología y estructura de las comunidades de peces en las lagunas costeras con bocas efímeras del Pacífico de México. Centro Cienc. Mar. Limnol., UNAM. Publ. Esp.2: 1-306. 